\title{
The Ancient Grave of Troloyo in Trowulan
}

\author{
Slamet Sujud Purnawan Jati \\ History Department Universitas Negeri Malang \\ E-mail: slamet.sujud.fis@um.ac.id \\ Deny Yudo Wahyudi \\ History Department Universitas Negeri Malang \\ E-mail: deny.yudo.fis@um.ac.id
}

\section{Doi:10.5901/mjss.2016.v7n4p512}

\begin{abstract}
This study aims to know the existence of Troloyo grave site background, to reconstruct the ancient of Troloyo grave site, and to explain its cultural continuity. The data were collected through observation, documentation, and interview. This was elaborated by typological, technological, and contextual analyses. The findings are (1) existence of Troloyo grave site as the tombs of Majapahit king's families shows people's religion conversion to Islam. The court places the Troloyo into the centre of Islamic community settlement and the centre of Islamic development; (2) the grave site of Troloyo basically is not properly arranged but is distributed into some areas of the bounded fence wall, the covered "cungkup" or the opened grave; (3) the decorated kind and the form of Troloyo Islamic grave depicts a cultural continuity of pre-Islamic period.
\end{abstract}

Keywords: cultural continuity, Islamic grave site, Majapahit

\section{Introduction}

In the context of History of Indonesia periodization, the fifteen and sixteen century is signed by the significant development of the Islamic culture. This period is called by the process of Islamization (Damais, 1995:178). Based on Islamic archaeological remains in East Java, these heritage spreads in the port cities of Majapahit, not only the ports around the north coast of East Java or Brantas River but also the hinterland around the palace of Majapahit. Many people claim that Islamic culture grows and develops in East Java along with the time of the collapse of Majapahit kingdom and the emergence of Demak kingdom as a first Islamic sultanate in Java (Mustopo, 2001:2-3). The knowledge about Islamic culture in the transition of East Java hinterland is important to expand the process of Islamization in the hinterland society believing on Hinduism-Buddhism. In addition, this study aims to know the history of architectural art and ornamental art showing the elements of pre-Islamic culture.

The form of cultural change is shaped by its phase of evolution. Therefore, culture could change suddenly but step by step. This change might create a concept or a material culture meeting mutually and even might shape an acculturation between the old and the recent (Kaplan \& Manners, 1999). This phenomenon is called by cultural continuity. In the process of Indonesian history, it is often that the cultural continuity followed by community's local genius.

The culture of transition is an appearing concept to the phenomenon of transition period between the past and at present condition. In this context, the transition directs into the Hinduism and Buddhism to Islam. The transitional culture brings the consequence for the material culture came from thirteen and sixteen century and even till eighteen century. The appearing form is a syncretism between pre-Islamic culture, which is Hinduism-Buddhism or prehistory, and Islamic culture arriving to Nusantara (Mustopo, 2001). The transitional culture is seemed by the remains of grave dominated by the merger of Hinduism and Islamic concept in the ideological and material-cultural level.

The site of grave is one of the old archaeological remains from material culture in the period of Indonesia-Islam. In the grave complex, ornamentation could be seen at the gateway and the building. Ceramic ornamentation, antefix, and top-side of building resembling the temple and commonly equipped by the spread calligraphy in medallion motive in the corner of building. In addition, the grave could be seen from the other ornamentation like antefix or ornamental antefix in base of grave, ornamentation in headstone, and calligraphy patching in jirat (Ambary, 1998; Tjandrasasmita, 2009).

The knowledge on cultural continuity in archaeological Islam Troloyo is important. This relates to the view of Islamic development between fifteen and sixteen century. However, this development is not a sudden development and 
changes the previous culture but assimilates evolutionary. Even, Graaf \& Pigeaud (1989:3) states that historical study on Hinduism-Buddhism and Islam has a depth gap. The end of Majapahit Kingdom is claimed as the ancient civilization collapse. According to Damais (1995:260), the religious changing from Hindu-Buddha to Islam takes place step by step and peaceful. This process is being a powerful framework for its growing of Islamic culture characterizing by both cultures.

\section{Method}

This study used archaeological-qualitative approach. This study started from August to November 2015. The data collection was done by the researchers helped by the students of History Department, Universitas Negeri Malang. The chosen place was a site of Troloyo. Specifically, this archaeological study concerned on historical-archaeological study by combining the method of archaeology and history of art. This study followed some steps. Those were (1) documenting artefactual and textual data and (2) interpreting those remains by the use of cultural continuity theory. This study took a place in Sidodadi Sub-Village, Sentonorejo Village, Trowulan Sub-District, and Mojokerto District. This study focused on the site complex of Troloyo grave. The Troloyo grave was chosen because of one of the important remains in the Islamic development of Majapahit period.

The data was the background of Troloyo grave site existence; the archaeological site of Troloyo grave based on its periodization; and the cultural continuity in its site of Troloyo grave. This study used primary and secondary sources (Sjamsuddin, 1996). Those primary sources were artefactual data such as architectural building comprising grave, mosque, gate, headstone, tomb, and others. In addition, the secondary sources were some literatures related to this study. The data collection comprised observation, library research, and interview. The researcher used some analyses of typological analysis, technological analysis, and contextual analysis (Soejono, 1982; Sukendar, 1999).

The typological analysis was done to provide information on the types of headstones in Troloyo. The verification was done by observing to the form of all headstones then classified based on the similarity of the type. The technological analysis was used to gain information on the artefactual material. The function was to help the age of artefactual analysis. the last, contextual analysis was useful to get information on the relationship between one and other artefact. This was important to know the relationship between history and the art style. Those analyses would be more elaborated by some theories and the researcher's logical thought.

\section{Finding and Discussion}

\subsection{The Existence of the Troloyo Site in Trowulan}

The grave site of Troloyo has its uniqueness. It is a site having the grave of Islamic remains. However, this remains are from the period of Majapahit kingdom, the base of Hindus Kingdom. One of the graves, which is most visited by the pilgrim, is the grave of Sheikh Jumadil Qubro. Sheikh Jumadil Qubro seems to be an important figure which have a big role in the process of Islamization in the areas of Majapahit Kingdom.

Santoso (2008, p.293) explained that Sheikh Jumadil Qubro is a pioneer of Islamic spread in the kingdom of Majapahit. Based on historical literature and Babad Tanah Jawi, he is well known as the ancestor of Sunan Ampel, Sunan Bonang, Sunan Gunung Jati, and the other walis (Bruinessen, 2012, p.277). In addition, Nasiruddin (2004, p.3) points out that most of Walisangas are of Sheikh Jumadil Qubro's descent. Therefore, he is called as the punjer of Walisanga.

According to Wahab (2008, p.289), the appearance of Sheikh Jumadil Qubro was expected during the reign of Hayam Wuruk. Sheikh Jumadil Qubro had an important role to spread Islam. Even, he was still struggling to convert the Majapahit in his old day. Sheikh Jumadil Qubro died when the Majapahit kingdom was ruled by Hayam Wuruk, which was in $1376 \mathrm{AD}$ and was buried in Troloyo. At present, the Islamic tombstones presence in the grave complex of Troloyo supports a claim of Islamic settlement in the glorious period of Majapahit Kingdom.

L.C. Damais in Ihami $(2015$, p.12) found that there are 44 ancient and andesite headstones in the grave site of Troloyo. Seven of those headstones have a numbering-year script. The oldest headstone comes from 1203 S (1281 AD) and the recent is $1533 \mathrm{~S}(1611 \mathrm{AD})$. Both findings lead us to assume that there are some people converting their beliefs to Islam. In addition, there is some headstones decorated with the Surya Majapahit and written in 1349 S (1427 AD), in $1387 \mathrm{~S}(1465 \mathrm{AD})$, and in $1389 \mathrm{~S}$ (1467 M). Those are written in ancient Javanese number. On the reverse side, it is contained the shahada written in Arabic. People assume that the headstones are the grave of royal relatives of the King Majapahit. However, they have already believed in Islam. 
Mustopo (2001, p.92) added that there are some headstones which are not identified by Damais. Those are the headstones from 1270 S (1348 AD), 1324 S (1402 AD), 1351 S (1429 M) and 1390 S (1468 AD). It could be clearly seen that the headstones refer to the Majapahit period between the reign of Tribhuwana Tunggadewi (1328-1350) and the reign of Hayam Wuruk (1350-1389). Therefore we could argue that the appearance of Islamic community or society in the capital of Majaphit Kingdom is from XIII AD to XVII AD. This shows to the beginning and the collapse of Majaphit Kingdom from the stage of history.

The existence of headstones in the grave of Troloyo also indicates that there have been a meeting, a reciprocal influence, and a continuity of two different cultures. Tjandrasasmita (2009) explained that the Islamic headstones in Troloyo prove the state of tolerance. They seem to allow the Muslim traders building their communities. Troloyo is placed as a centre of Islamic development. This is a time of religious conversion from Hindu-Buddha to Islam. It could be clearly seen that most Islamic people in Troloyo and Trowulan are Javanese which has been Islamized.

\subsection{The Archaeological Evidents of Troloyo Site in Trowulan}

The grave site of Troloyo is located in Sidodadi Sub-Village, Sentanarejo Village, Trowulan Sub-district, Mojokerto District. This site is approximately 15 kilometers west of the city of Mojokerto. The grave has some boundaries. The north refers to the settlement of Sentonorejo Village; the east is near from the village street; the south faces the Pakis village; and the west is near from the people's rice field. Generally speaking, the graves in Troloyo are not in a group but in a separated areas approximately $125 \times 100 \mathrm{~m}$. Some of the graves are in small groups surrounded by the stone-wall. The others are separated tombs.

The site complex of Troloyo is divided into two groups of grave. The first is located in the front or in the southeast adn the second is located in the back or the northwest. The first group consists of the grave of Tumenggung Satim Singomoyo, the grave of Sheikh Al-Chusen, the grave of Imamudin Sofari, the footstep of Walisanga, the grave of Patas Angin, the grave of Nyai Roro Kepyur, the grave of Tiga, the grave of Sheikh Jumadil Qubro, and the grave of Sheikh Ngudung. The second group comprises of two graves including two famous tomb called the grave of Raden Ayu Anjasmoro and Raden Ayu Kencono Wungu. There are five graves in the north and two graves in the south. Those graves are called as the pitu grave, the grave of Sheikh Rochim, the grave of Sheikh Djaelani, the grave of Sheikh Qohar, the grave of Notonegoro, and the grave of Mbah Rembyong.

Chronologically, it could be identified the oldest and the recent grave. The oldest grave in Troloyo site is the grave of Tujuh, followed by the grave of Sheikh Ngudung, the grave of Syech Jumadil Qubro, the grave of Tiga, the footstep of Walisanga, the grave of Tumenggung Satim Singomoyo, the grave of Patas Angin, the grave of Nyai Roro Kepyur, the grave of Raden Ayu Kencono Wungu, the grave of Ki Ageng Surgi, the grave of Notonegoro, the grave of Syech Qohar, the grave of Syech Abdurochim, and the grave of Mbah Rembyong.

Most jirat in Troloyo is foursquare shape, white-cleaning colour, and without ornamentation. The long-size of jirat is being an interesting grave. Jirat of Sheikh Ngudung grave is called by the long grave, around $550 \mathrm{~cm}$ an $76 \mathrm{~cm}$. The sixe of grave does not represent the man but it is completely the appreciating sign due to the effort in spreading Islam in East Java. Meanwhile, the headstone in the site shapes the curly brackets, the convex side or straight to short into the lower base, and the corner bottom shapes the antefixs. Most headstones have the ornamentation of Surya Majapahit representing Hinduism-Buddhism and are written the year. In addition, the headstone has some Arabic written inscription. Based on L.C. Damais in Ilhami (2005:12),the oldest headstone is $1203 \mathrm{~S} \mathrm{(1281} \mathrm{AD)} \mathrm{and} \mathrm{the} \mathrm{recent} \mathrm{is} 1533 \mathrm{~S} \mathrm{(1611}$ $A D)$. In the site, we could find the artefacts like the huge bricks. The bricks are estimated as the traces of a building which is not reconstructed. We could assume that this building came from the Majapahit period.

\subsection{Cultural Continuity in the Ancient Grave of Troloyo}

The existence of Islamic headstones in the grave site in Troloyo signs twofold. First, Islam spreads not only in the north coast of East Java but also affects to the centre of Majapahit kingdom. Second, Islamic-archaeological data sources are the real fact in convincing the Muslim communities in XIV AD Majapahit.

Previous studies, from Damais to Casparis, the ancient Javanese number in the headstone of Troloyo is affected by the bold Arabic writing. This shows that the beginning of Islamic development in East Java happening a reciprocal effect between two different cultures. The style of Arabic writing in Islamic headstone in Troloyo having a year is a local calligraphy (Mustopo, 2002, p.6). In addition, the characteristic of ornamentation and the Arabic writing indicates the meeting between the Javanese-Hinduism tradition of Majapahit and Islam period. Damais in Wahab $(2008, p .87)$ states that the headstone has an ornamentation of Hinduism-Buddhism which is often to use in the building of Majapahit period. 
The ornamentation covers some designs. Those are the Surya Majapahit design and geometric design. The Surya Majapahit design is characterized by climbing plant and flower. The geometric design is seemed to be hexagonal and edge of cloud. The continuity of Hinduistic and Javanese art in the Islamic grave site shows the local wisdom which exists.

The archaeological fact like a headstone with Surya Majapahit motive and some findings of huge bricks represent the Majapahit building. This fact shows there is a cultural continuity in the grave site in the period of transitional time. The ornamentation of Majapahit light representing the light circle in the history of ornamentation in Nusantara. The ornamentation is most used in Majapahit art. The circle of light, called by Dutch Archaeologist as stralenskrans, is reserved for the Gods and the Man-God (Mustopo, 2001:218). This circle of light is a lightening showing the supra natural power of the displayed figure.

The huge bricks show that the grave site has ever standed the sacred or profane buildings. Those buildings are came from the Hinduism-Buddhism period, mainly Majapahit period. In addition, the study found that some elements of Hinduism-Buddhism culture is re-used in the beginning of Islamic development mainly, re-utilizing the HinduismBuddhism site as an Islamic grave site. The re-use of Hinduism-Buddhism elements in the grave site of Troloyo in the beginning of Islamic development aims to bridge the gap of Islamic knowledge. Therefore, people in Malang could accept the Islamic teaching. In addition, Islamization in Malang could be smoothly run.

The Islamic spread could be accepted if the leaders are first islamized, therefore all societies are automatically islamized. The form of Islam in Majapahit is not in simple teaching and barbarian culture, but facing the civilized society. the entrance of Islam in Majapahit is a part of cultural continuity with the previous culture.

The process of Islamic development in Majapahit, Sheikh Jumadil Qubro has a significant role. He could be Islamizing society in the time of most people believing in Hinduism-Buddhism. Therefore, the process of Islamization needs a tolerance showed by Sheikh Jumadil Qubro. He could deliver a propaganda to elite and could contextualize to the society at the time. One of logical consequeces is the appearance of syncretism (Iskandar, 2001, p.49). However, the Islamized society could still continue the previous culture. It is common in society but they should adapt the Islamic teaching and law. Therefore, Sheikh Jumadil Qubro becomes a role model and his grave could be people's destination to pilgrimage in searching blessings.

\section{Conclusion}

The Troloyo grave site is a fact directing into Islamic settlement in the period of Majapahit Kingdom. This study assumes that the graves represent the Islamic royal relatives. In addition, the headstones direct us to think any tolerance in the multicultural state. The government could accept the Islamic traders in Majapahit. They permit and allow them to stay and to form their communities. Troloyo is placed as a centre of Islamic development. This influences people to convert their religion. This fact leads us to know that all Islamic communities in Troloyo and Trowulan are the Islamized Javanese.

Generally speaking, the graves in Troloyo are not in a group but in a separated areas approximately $125 \times 100 \mathrm{~m}$. Some of the graves are in small groups surrounded by the stone-wall. The others are separated tombs. Chronologically, it could be identified the oldest and the recent grave. The oldest grave in Troloyo site is the grave of Tujuh, followed by the grave of Sheikh Ngudung, the grave of Syech Jumadil Qubro, the grave of Tiga, the footstep of Walisanga, the grave of Tumenggung Satim Singomoyo, the grave of Patas Angin, the grave of Nyai Roro Kepyur, the grave of Raden Ayu Kencono Wungu, the grave of Ki Ageng Surgi, the grave of Notonegoro, the grave of Syech Qohar, the grave of Syech Abdurochim, and the grave of Mbah Rembyong.

The headstones in the grave of Troloyo are written in Arabic and ancient Javanese. The ornamental representation and shape in Islamic grave is seemed to be a historical continuity from pre Islamic period. This is supported by the Hinduism-Buddhism ornamentation in Majapahit Building. The characteristic of ornamentation refer to the sign of Surya Majapahit. This cultural continuity shows that people have the local genius. They could collaborate the newest culture along with the previous culture. The archaeological fact of the transitional time deals with the headstone which has Surya Majapahit ornamentation. Some huge bricks supports the assumption that there are many building using the style of Majapahit era. The presence of the headstone signs a meeting, a reciprocal effect, and a continuity between two different cultures.

\section{References}

Ambary, H.M. 1998. Menemukan Peradaban: Arkeologi dan Islam di Indonesia. Jakarta: Pusat Penelitian Arkeologi Nasional. Bruinessen, M. van. 2012. Kitab Kuning, Pesantren dan Tarekat. Yogyakarta: Gading Publishing. 
Damais, L.C. 1995. Epigrafi dan Sejarah Nusantara, Pilihan Karangan L.C. Damais. Jakarta: EFEO \& Pusat Penelitian Arkeologi Nasional.

Graaf, H.J. \& Pigeaud, Th. G. Th. 1989. Kerajaan-Kerajaan Islam di Jawa: Kajian Sejarah Politik Abad ke-15 dan ke-16. Jakarta: Pustaka Grafiti.

Ilhami, dkk. 2005. Mengintip Surya Majapahit di Makam Troloyo: Makam Nenek Moyang Walisanga, Tetenger Brawijaya V Masuk Islam. Mojokerto: Bhumi Majapahit.

Iskandar, M. 2001. Para Pengemban Amanah. Yogyakarta: Mata Bangsa.

Kaplan, D \& Manners, A.A. 1999. Teori Budaya. Yogyakarta: Pustaka Pelajar.

Mustopo, M.H. 2001. Kebudayaan Islam di Jawa Timur: Kajian Beberapa Unsur Budaya Masa Peralihan. Yogyakarta: Jendela Grafika.

Mustopo, M.H. 2002. Lintas Budaya Pada Masa Peralihan di Jawa Timur Abad XV-XVI M (Kontinuitas dalam Budaya Islam). Pidato pengukuhan Guru Besar disampaikan pada Sidang Terbuka Senat Universitas Negeri Malang, Bidang IImu Arkeologi FS UM. Malang, 3 September.

Nasiruddin, M.C. 2004. Punjer Walisanga: Sejarah Syech Jumadil Qubro. Jombang: Semma.

Santoso, J. 2008. Kompleks Makam Troloyo. Dalam Wahib Wahab (Ed). 700 Tahun Majapahit (1293-1993) Suatu Bunga Rampai (hlm. 293-296). Surabaya: Dinas Pariwisata Daerah Propinsi Daerah Tingkat I Jawa Timur.

Sjamsuddin, H. 1996. Metodologi Sejarah. Jakarta: Depdikbud.

Soejono, R.P. (Ed). 1982. Buku Pegangan Metode Penelitian Arkeologi. Jakarta: Puslitarkenas.

Sukendar, H. (Ed). 1999. Metode Penelitian Arkeologi. Jakarta: Puslitarkenas.

Tjandrasasmita, U. 2009. Arkeologi Islam Nusantara. Jakarta: Kepustakaan Populer Gramedia.

Wahab, W. 2008. Syeikh Jumadil Qubro: Biografi dan Perjalanan Dakwahnya. Dalam Wahib Wahb (Ed). Syeikh Jumadil Qubro Punjer Walisanga: Perspektif Historis, Arkeologis, Sosiologis, Antropologis, dan Religius. (hlm 29-42; 288-292). Mojokerto: Pemkab Mojokerto. 